\title{
Table of treaties and decisions
}

\section{TREATIES}

1945 Charter of the United Nations, 1

UNTS XVI 66,68

1969 Vienna Convention on the Law of

Treaties, 1155 UNTS 331 ...9, 62-6, 68-70, 73, 100, 108, $138,140,183,186-90$, 192, 203, 209, 221-2

1982 United Nations Convention on the Law of the Sea, 1833

UNTS 3 $24,36,46,186$

1987 Montreal Protocol on Substances that Deplete the Ozone Layer, 1522 UNTS 3 .....23-4, 54, 70, 94, 165, 190-91, 207, 211, 224,233

1992 United Nations Convention on Biological Diversity, 1760 UNTS 79 126-8, 140, 143,145

1992 United Nations Framework Convention on Climate Change, 1771 UNTS 163 17-18, 63, 87-88, 104-106, 110, 121-2, $142,145,165,173,182,185$, $190,194,224$

1994 Agreement on Subsidies and Countervailing Measures, 1869 UNTS 183 168-71

1994 Agreement on Technical Barriers to Trade, 1868 UNTS 120 ...161-2, 173

1994 Agreement on Trade-Related Aspects of Intellectual Property Rights, 1869 UNTS 299 ......41, 51, 160,173
1994 Agreement on Trade-Related Investment Measures, 1868 UNTS 186 169-70

1994 General Agreement on Trade in Services, 1869 UNTS

183 $160,167-8$

1994 General Agreement on Tariffs and Trade, 1867 UNTS 187 ..160, 162-3, 165, 167-9, 171-3, 177-80, 183-7, 203, 222

1994 Marrakesh Agreement Establishing the World Trade Organization, 1867 UNTS 3 ......62, 160-61, 187-8, 192, 194

1997 Kyoto Protocol to the United Nations Framework Convention on Climate Change, 2303 UNTS 148 $19,21,89,106,122-3$, $139,142,145,166,169-70$, $182,194,224$

1997 United Nations Convention on the Law of the Non-Navigational Uses of International Watercourses, 36 ILM 700 .66

\section{DECISIONS BY THE CBD COP}

Decision II/8, Preliminary

Consideration of Components of

Biological Diversity Particularly

Under Threat and Action Which

Could be Taken under the

Convention, UN Doc. UNEP/

CBD/COP/2/19 (30 November 1995) 
Decision III/12, Programme of Work for Terrestrial Biological Diversity: Forest Biological Diversity, UN Doc. UNEP/CBD/COP/3/38 (11 February 1997) .128

Decision IV/7, Forest Biological Diversity, UN Doc. UNEP/CBD/ COP/4/27 (15 June 1998) 128

Decision V/4, Progress Report on the Implementation of the Programme of Work on Forest Biological Diversity, UN Doc. UNEP/CBD/ COP/5/23 (22 June 2000) 143

Decision V/6, Ecosystem Approach, UN Doc. UNEP/CBD/COP/5/23 (22 June 2000)

Decision VI/22, Forest Biological Diversity, UN Doc. UNEP/CBD/ COP/6/20 (27 May 2002) 128

Decision VII/15, Biodiversity and Climate Change, UN Doc. UNEP/ CBD/COP/7/21 (13 April 2004) 143

Decision VII/26, Cooperation with Other Conventions and International Organizations and Initiatives, UN Doc. UNEP/CBD/ COP/7/21 (13 April 2004) .76

Decision VIII/30, Biodiversity and Climate Change: Guidance to Promote Synergy among Activities for Biodiversity Conservation, Mitigating or Adapting to Climate Change and Combating Land Degradation, UN Doc. UNEP/CBD/COP/DEC/ VIII/30 (15 June 2006) .143

Decision IX/5, Forest Biodiversity, UN Doc. UNEP/CBD/COP/DEC/IX/5

(9 October 2008) .83

Decision IX/16, Biodiversity and Climate Change, UN Doc. UNEP/ CBD/COP/DEC/IX/16 (9 October 2008) 143-3, 147

Decision X/2, The Strategic Plan for Biodiversity 2011-2020 and the Aichi Biodiversity Targets, UN
Doc. UNEP/CBD/COP/DEC/X/2

(29 October 2010) 147

Decision X/20, Cooperation with Other Conventions and International Organizations and Initiatives, UN Doc. UNEP/CBD/COP/DEC/ $\mathrm{X} / 20$ (29 October 2010) 144

Decision X/33, Biodiversity and Climate Change, UN Doc. UNEP/ CBD/COP/DEC/X/33 (29 October 2010) ..........129, 144, 147

Decision XI/19, Biodiversity and Climate Change Related Issues: Advice on the Application of Relevant Safeguards for Biodiversity with Regard to Policy Approaches and Positive Incentives on Issues Relating to Reducing Emissions from Deforestation and Forest Degradation in Developing Countries; and the Role of Conservation, Sustainable Management of Forests and Enhancement of Forest Carbon Stocks in Developing Countries, UN Doc. UNEP/CBD/COP/11/35

(5 December 2012) 145

\section{DECISIONS BY THE} KYOTO PROTOCOL COP/MOP

Decision 1/CMP.1, Consideration of Commitments for Subsequent Periods for Parties Included in Annex I to the Convention under Article 3, Paragraph 9, of the Kyoto Protocol, UN Doc. FCCC/ KP/CMP/2005/8/Add.1 (30 March 2006)

Decision 5/CMP.1, Modalities and Procedures for Afforestation and Reforestation Project Activities under the Clean Development Mechanism in the First 
Commitment Period of the Kyoto Protocol, UN Doc. FCCC/KP/ CMP/2005/8/Add.1 (30 March 2006) $124,131-2$

Decision 15/CMP.1, Guidelines for the Preparation of the Information Required Under Article 7 of the Kyoto Protocol, UN Doc. FCCC/ KP/CMP/2005/8/Add.2 (30 March 2006) 132

Decision 16/CMP.1, Land Use,

Land-use Change and Forestry, UN Doc. FCCC/KP/CMP/2005/8/ Add.3 (30 March 2006) .......131-2 Decision 2/CMP.5, Further Guidance Relating to the Clean Development Mechanism, UN Doc. FCCC/KP/CMP/2009/21/ Add.1 (30 March 2010) 169

Decision 1/CMP.8, Amendment to the Kyoto Protocol pursuant to its Article 3, paragraph 9 (the Doha Amendment), Decision proposed by the President, UN Doc. FCCC/ KP/CMP/2012/13/Add.1 (28

February 2013) .22

\section{DECISIONS BY THE UNFCCC COP}

Decision 1/CP.1, The Berlin Mandate:

Review of the Adequacy of Article 4, paragraph 2(a) and (b), of the Convention, Including Proposals

Related to a Protocol and Decisions on Follow-up, UN Doc. FCCC/CP/1995/7/Add.1 (6 June 1995) 19

Decision 12/CP.2, Memorandum of Understanding between the Conference of the Parties and the Council of the Global Environment Facility, UN Doc. FCCC/CP/1996/15/Add.1 (29 October 1996)
Decision 4/CP.7, Development and Transfer of Technologies (Decisions 4/CP.4 and 9/CP.5), UN Doc. FCCC/CP/2001/ 13/Add.1 (21 January 2002) $89-90,110$

Decision 17/CP.7, Modalities and Procedures for a Clean Development Mechanism, as Defined in Article 12 of the Kyoto Protocol, UN Doc. FCCC/CP/ 2001/13/Add.2 (21 January 2002)

Decision 13/CP.8, Cooperation with Other Conventions, UN Doc. FCCC/CP/2002/7/Add.1

(28 March 2003) 142,233

Decision 19/CP.9, Modalities and Procedures for Afforestation and Reforestation Project Activities Under the Clean Development Mechanism in the First Commitment Period of the Kyoto Protocol, UN Doc. FCCC/CP/ 2003/6/Add.2 (30 March 2004)

Decision 1/CP.11, Dialogue on

Long-term Cooperative Action to

Address Climate Change by

Enhancing Implementation of the Convention, UN Doc. FCCC/CP/ 2005/5/Add.1 (30 March 2006)

Decision 1/CP.13, Bali Action Plan, UN Doc. FCCC/CP/2007/6/Add.1 (14 March 2008) 21,91 $107,124,182,200$

Decision 2/CP.13, Reducing Emissions from Deforestation in Developing Countries: Approaches to Stimulate Action, UN Doc. FCCC/ CP/2007/6/Add.1 (14 March 2008) 124,135

Decision 3/CP.13, Development and Transfer of Technologies under the Subsidiary Body for Scientific and Technological Advice, UN Doc. 
FCCC/CP/2007/6/Add.1 (14

March 2008)

Decision 2/CP.14, Development and

Transfer of Technologies, UN

Doc. FCCC/CP/2008/7/Add.1 (18

March 2009)

Draft Decision -/CP.15, Policy

Approaches and Positive

Incentives on Issues Relating to

Reducing Emissions from

Deforestation and Forest

Degradation in Developing

Countries; and the Role of

Conservation, Sustainable

Management of Forests and

Enhancement of Forest Carbon

Stocks in Developing Countries,

UN Doc. FCCC/AWGLCA/2009/

L.7/Add.6 (15 December 2009) .21

Decision 2/CP.15, Copenhagen Accord,

UN Doc. FCCC/CP/2009/11/

Add.1 (30 March 2010) .....92, 125

Decision 4/CP.15, Methodological

Guidance for Activities Relating to

Reducing Emissions from

Deforestation and Forest

Degradation and the Role of

Conservation, Sustainable

Management of Forests and

Enhancement of Forest Carbon

Stocks in Developing Countries,

UN Doc. FCCC/CP/2009/11/

Add.1 (30 March 2010) ...125, 135

Decision 1/CP.16, Outcome of the Work

of the Ad Hoc Working Group on

Long-term Cooperative Action under the Convention, UN Doc.

FCCC/CP/2010/7/Add.1 (15

March 2011) ........16, 22, 92, 109, $125,135-6,145,183$

Decision 1/CP.17, Establishment of an

Ad Hoc Working Group on the

Durban Platform for Enhanced

Action, UN Doc. FCCC/CP/2011/

9/Add.1 (15 March 2012) 22

Decision 2/CP.17, Outcome of the work of the Ad Hoc Working Group on

Long-term Cooperative Action under the Convention, UN Doc. FCCC/CP/2011/9/Add.1 (15

March 2012) .92

Decision 3/CP.17, Launching the Green Climate Fund, UN Doc. FCCC/ CP/2011/9/Add.1 (15 March 2012) .112

Decision 12/CP.17, Guidance on

Systems for Providing

Information on How Safeguards

Are Addressed and Respected and Modalities Relating to Forest

Reference Emission Levels and Forest Reference Levels as Referred to in Decision 1/CP.16, UN Doc. FCCC/CP/2011/9/Add. 2 (15 March 2012) ........126, 135-6, 145

Decision -/CP.19, The Timing and the Frequency of Presentations of the Summary of Information on How All the Safeguards Referred to in Decision 1/CP.16, Appendix I, Are Being Addressed and Respected, Advance Unedited Version. ....136 
Harro van Asselt - 9781782544982 Downloaded from PubFactory at 04/26/2023 $08: 31: 36 \mathrm{AM}$ via free access 